\title{
Home Parenteral Nutrition Therapy in Seven Patients with Anorexia Nervosa: The Role and Indications
}

\author{
Mari Hotta ${ }^{1,2}$, Mariko Araki ${ }^{3}$, Ayako Urano ${ }^{4}$ and Rina Ohwada ${ }^{4}$
}

\begin{abstract}
Home parenteral nutrition (HPN) is a well-established intervention to sustain life in malnourished patients at home. Because it is difficult for patients with anorexia nervosa (AN) to gain weight or stop purging, such patients require repeated hospitalizations. Although HPN has not been commonly used for AN patients in Japan, we utilized this approach to treat seven AN patients. We herein present the clinical course and outcome of these seven patients, the application criteria for HPN in our institution, and the potential problems associated with HPN. Despite its complications, HPN may be a useful measure to help patients with persistent AN avoid multiple hospitalizations.
\end{abstract}

Key words: anorexia nervosa, home parenteral nutrition, indication, catheter-related blood stream infection

(Intern Med 53: 2695-2699, 2014)

(DOI: 10.2169/internalmedicine.53.3023)

\section{Introduction}

Patients with anorexia nervosa (AN) develop anorexia or binge eating with purging as a stress-coping mechanism that serves to distract them from difficulty or pain. Because patients with AN do not readily accept body weight gain or cease binge eating/purging, it seems unlikely that patients with serious AN (along with physical and psychological comorbidities) will respond to psychotherapy. Such patients at high risk of death (1) require repeated hospitalizations and the use of total parenteral nutrition (TPN) to treat their complications or save their lives (2-4).

There are no eating disorder centers in Japan, and therefore patients with serious AN have to enter hospital wards in departments where the medical staff is not familiar with the illness or abnormal behaviors of patients with AN and, thus, less able to cope with or treat them. Recently, the Ministry of Health, Labour and Welfare in Japan has promoted home medical care to reduce medical expenses. Home parenteral nutrition (HPN) is a well-established intervention that can sustain life in patients with gastrointestinal failure or cancer. In Western countries, HPN has been used for patients with
AN since the 1980s (5). It is difficult to determine whether patients with AN can successfully use HPN, as there are only a few reports on HPN in patients with $\mathrm{AN}$, and the role and indications for HPN therapy in such studies are mostly not discussed $(6,7)$.

Although HPN has not been commonly used in patients with AN in Japan, we used HPN in seven women with severe and/or long-term AN. We herein report the clinical profiles of the patients, reasons for use of HPN, details of HPN, and outcomes of these patients, as well as the criteria for use of HPN for AN patients in our institution.

\section{Case Reports}

HPN was used in the treatment of seven women (Table). Patients were diagnosed with AN based on the Diagnostic and Statistical Manual for Mental Disorders, 5th edition, in addition to the criteria of AN put forth by the Survey Committee for Eating Disorders of the Japanese Ministry of Health, Labour and Welfare (8) which includes: 1) $\geq 20 \%$ weight loss of standard weight lasting longer than 3 months; 2) abnormal eating behavior, including food restriction, bulimic episodes, and stealth eating; 3 ) disturbances in the pa-

\footnotetext{
${ }^{1}$ Health Services Center, National Graduate Institute for Policy Studies, Japan, ${ }^{2}$ Institute of Women's Health, Tokyo Women's Medical University, Japan, ${ }^{3}$ Department of Internal Medicine, Nagai Hitachinomori Hospital, Japan and ${ }^{4}$ Division of Endocrinology and Metabolism, Saitama Sekishinkai Hospital, Japan

Received for publication April 4, 2014; Accepted for publication May 21, 2014

Correspondence to Dr. Mari Hotta, marihs@grips.ac.jp
} 
Table. Summary of Clinical Profiles, Details of Home Parental Nutrition (HPN), and Outcomes in Seven Cases with Anorexia Nervosa

\begin{tabular}{|c|c|c|c|c|c|c|c|}
\hline Case No & 1 & 2 & 3 & 4 & 5 & 6 & 7 \\
\hline Age of onset (years) & 17 & 23 & 17 & 20 & 20 & 14 & 18 \\
\hline Type & Restricting & Restricting & Restricting & $\begin{array}{l}\text { Binge eating } \\
\text { /Purging }\end{array}$ & $\begin{array}{l}\text { Binge eating } \\
\text { /Purging }\end{array}$ & $\begin{array}{l}\text { Binge eating } \\
\text { /Purging }\end{array}$ & $\begin{array}{l}\text { Binge eating } \\
\text { /Purging }\end{array}$ \\
\hline $\begin{array}{l}\text { Psychological } \\
\text { comorbidity }\end{array}$ & Anxiety disorder & & $\begin{array}{l}\text { Obsessive- } \\
\text { compulsive } \\
\text { disorder } \\
\end{array}$ & & Depression & $\begin{array}{l}\text { Obsessive- } \\
\text { compulsive } \\
\text { disorder }\end{array}$ & $\begin{array}{l}\text { Personality } \\
\text { disorder }\end{array}$ \\
\hline Hospitalization (times) & 14 & 9 & 6 & 12 & 14 & 5 & 10 \\
\hline BMI on entry $(\% \mathrm{IBW})$ & $11.9(54.3)$ & $10.3(47.8)$ & $12.0(56.4)$ & $11.8(55.0)$ & $10.2(46.7)$ & $11.6(53.3)$ & $11.9(53.7)$ \\
\hline Indication for HPN & $\begin{array}{c}\text { Digestive } \\
\text { symptoms, } \\
\text { Phobia } \\
\end{array}$ & $\begin{array}{l}\text { Digestive } \\
\text { symptoms }\end{array}$ & Food allergy & $\begin{array}{l}\text { Electrolyte } \\
\text { imbalance }\end{array}$ & $\begin{array}{l}\text { Electrolyte } \\
\text { imbalance, } \\
\text { Renal failure }\end{array}$ & $\begin{array}{l}\text { Electrolyte } \\
\text { imbalance, } \\
\text { Renal failure }\end{array}$ & $\begin{array}{l}\text { Electrolyte } \\
\text { imbalance, } \\
\text { Renal failure }\end{array}$ \\
\hline $\begin{array}{l}\text { Type of central venous } \\
\text { access device }\end{array}$ & Broviac catheter & \multicolumn{6}{|c|}{ Implantation of infusion ports into the subcutaneous tissue of the chest } \\
\hline Infusion time & $\begin{array}{c}\text { continuous } \\
\text { 24-hour infusion }\end{array}$ & \multicolumn{6}{|c|}{ Cyclic (discontinuous) infusion } \\
\hline Operaters of HPN & Herself, Mother & Herself, Mother & Herself & Herself, Nurse & Father & Herself, Mother & Father \\
\hline Support system & Local hospital & $\begin{array}{l}\text { Local hospital, } \\
\text { Home-visit } \\
\text { nursing care }\end{array}$ & $\begin{array}{l}\text { Local hospital, } \\
\text { Home-visit } \\
\text { nursing care }\end{array}$ & Local hospital & $\begin{array}{l}\text { Local hospital, } \\
\text { Home-visit } \\
\text { nursing care }\end{array}$ & $\begin{array}{l}\text { Home-visit } \\
\text { nursing care }\end{array}$ & $\begin{array}{l}\text { Home-visit } \\
\text { nursing care }\end{array}$ \\
\hline $\begin{array}{l}\text { Intravenous feeding } \\
\text { contents }\end{array}$ & $\begin{array}{c}1,160 \\
\text { Fat }(1 / \text { week })\end{array}$ & $\begin{array}{c}1,160 \mathrm{kcal} \\
\text { Fat }(1 / \text { week })\end{array}$ & $860 \mathrm{kcal}$ & $1,160 \mathrm{kcal}$ & $\begin{array}{c}1,160 \mathrm{kcal} \\
\text { Fat }(1 / \text { week })\end{array}$ & $\begin{array}{c}1,160 \mathrm{kcal} \\
\text { Fat }(1 / \text { week })\end{array}$ & $\begin{array}{c}1,500 \mathrm{kcal} \\
\text { Fat }(1-2 / \text { week })\end{array}$ \\
\hline Energy/kg BW (kcal) & 50.4 & 43.4 & 27.1 & 37.8 & 40.0 & 43.1 & 51.7 \\
\hline $\mathrm{AA} / \mathrm{kg} \mathrm{BW}(\mathrm{g})$ & 1.74 & 1.50 & 0.95 & 1.30 & 1.38 & 1.49 & $0 . ; 99$ \\
\hline $\mathrm{NPC} / \mathrm{N}$ & 160 & 160 & 150 & 160 & 160 & 160 & 350 \\
\hline $\begin{array}{l}\text { HPN-related } \\
\text { complications }\end{array}$ & $\begin{array}{l}\text { Exit-site infection } \\
\text { Catheter damage } \\
\text { Liver dysfunction } \\
\text { Bile sludge }\end{array}$ & CRBSI & CRBSI & None & None & CRBSI & $\begin{array}{l}\text { Hypercalcemia } \\
\text { CRBSI }\end{array}$ \\
\hline $\begin{array}{l}\text { Outcome of HPN } \\
\text { Observation period } \\
\text { (months) }\end{array}$ & $\begin{array}{c}\text { Continued } \\
104\end{array}$ & $\begin{array}{l}\text { Ended owing to } \\
\text { BW gain and } \\
\text { CRBSI } \\
22 \\
\end{array}$ & $\begin{array}{l}\text { Ended owing to } \\
\text { BW gain and } \\
\text { CRBSI } \\
25 \\
\end{array}$ & $\begin{array}{c}\text { Ended owing to } \\
\text { BW gain } \\
22\end{array}$ & $\begin{array}{l}\text { Stopped owing to } \\
\text { fear of weight } \\
\text { gain } \\
38 \\
\end{array}$ & $\begin{array}{c}\text { Ended owing to } \\
\text { fear of weight } \\
14\end{array}$ & $\begin{array}{l}\text { Ended owing to } \\
\text { BW gain and } \\
\text { CRBSI } \\
26 \\
\end{array}$ \\
\hline $\begin{array}{l}\text { BMI at the end of } \\
\text { HPN }\left(\mathrm{kg} / \mathrm{m}^{2}\right)(\% \mathrm{IBW})\end{array}$ & & $\begin{array}{l}\text { Increased } \\
14.5(69.9)\end{array}$ & $\begin{array}{l}\text { Increased } \\
16.0(75.3)\end{array}$ & $\begin{array}{c}\text { Increased } \\
18.4(90.9)\end{array}$ & & $\begin{array}{l}\text { Unchanged } \\
11.8(53.5)\end{array}$ & $\begin{array}{l}\text { Increased } \\
14.4(67.7)\end{array}$ \\
\hline Present state & $\begin{array}{l}\text { Increased BW to } \\
14.7 \mathrm{~kg} / \mathrm{m}^{2} \\
(69.8 \%) \text { and then } \\
\text { decreased HPN } \\
\text { calorie }\end{array}$ & $\begin{array}{l}\text { Lost BW again } \\
\text { and be } \\
\text { hospitalized } \\
\text { twice }\end{array}$ & $\begin{array}{l}\text { Increased BW } \\
\text { to } 18.8 \mathrm{~kg} / \mathrm{m}^{2} \\
(86.0 \%) \text { and } \\
\text { resumed } \\
\text { menstruation }\end{array}$ & $\begin{array}{l}\text { Resumed } \\
\text { menstruation and } \\
\text { worked for } \\
\text { full-time job }\end{array}$ & $\begin{array}{l}\text { Increased BW to } \\
11.9 \mathrm{~kg} / \mathrm{m}^{2} \\
(54.8 \%) \text { but } \\
\text { hospitalized } \\
\text { twice due to } \\
\text { dehydration }\end{array}$ & $\begin{array}{l}\text { increased BW to } \\
13.1 \mathrm{~kg} / \mathrm{m}^{2} \\
(60.2 \%) \text { and } \\
\text { worked for } \\
\text { part-time job }\end{array}$ & $\begin{array}{l}\text { Kept BW, } \\
\text { become less } \\
\text { negatively for } \\
\text { treatment and } \\
\text { received } \\
\text { intravenous } \\
\text { injections } 3 \text { times } \\
\text { a week }\end{array}$ \\
\hline
\end{tabular}

BMI: body mass index, IBW: ideal body weight, BW: body weight, AA: amino acids, NPC/N: non-protein calorie/nitrogen ratio CRBSI: catheter-related blood stream infection

tient's perception of body weight or shape and intense fear of gaining weight despite being underweight; 4) onset at younger than 30 years; 5) amenorrhea in females; and 6) ruling out of other illnesses, including psychiatric disorders, that could account for anorexia and weight loss. The duration of illness before administration of HPN ranged from 3 to 20 years, and all patients had been hospitalized from 5 to 14 times. Cases 1-3 had restricting-type AN. Cases 1 and 2 could not increase their food intake due to stubborn digestive symptoms and a fear of eating. Because they could not tolerate any food in their stomach, they rejected enteral nutrition therapy. They also did not accept psychotherapy. Case 3 disliked eating rice, meat, and oily foods (typical of most patients with $\mathrm{AN}$ ) and had allergies to dairy and soy prod- ucts. She was also afraid of eating several kinds of foods. Case 3 required repeated hospitalizations due to lifethreatening emaciation without adequate oral feeding. TPN during hospitalizations increased her body weight; however, she quickly lost body weight soon after discharge. Although we recommended home enteral nutrition through an enteral diet containing amino acids, she preferred HPN to home enteral nutrition. Cases 4-7 had binge eating/purging-type AN complicated with pseudo-Bartter syndrome. Case 4 carried out habitual self-induced vomiting and abuse of a purgative. She had uncontrollable electrolyte imbalances (serum $\mathrm{Na}$, $124 \mathrm{mEq} / \mathrm{L} ; \mathrm{K}, 2.4 \mathrm{mEq} / \mathrm{L} ; \mathrm{Cl}, 76 \mathrm{mEq} / \mathrm{L}$ ) despite oral supplementation with sodium chloride and potassium chloride. Cases 5-7 also carried out habitual self-induced vomiting 
and showed dehydration, electrolyte imbalances, and renal failure. The lowest levels of serum $\mathrm{K}(\mathrm{mEq} / \mathrm{L}) / \mathrm{blood}$ urea nitrogen $(\mathrm{BUN} ; \mathrm{mg} / \mathrm{dL}) /$ creatinine $(\mathrm{mg} / \mathrm{dL})$ of Cases 5,6 , and 7 were 2.3/25.3/1.22, 2.5/62.9/5.78, and 2.9/75.4/8.38, respectively. All three patients repeated hospitalization due to hypokalemia and renal failure. Because the patients would vomit whatever was put into their stomachs, we did not administer enteral nutrition. Case 7 received percutaneous endoscopic gastrostomy because she had vomited approximately 2 liters per day; however, she vomited most of the nutrients she received from enteral nutrition. Therefore, she received intravenous injections of glucose and electrolyte solution $(1,000 \mathrm{~mL})$ three times a week after discharge.

All patients needed, but resisted, hospitalization for treatment of AN. Cases 1-3 did not accept enteral nutrition and we speculated that enteral nutrition therapy would be less effective for Cases 4-7 than parenteral nutrition due to their habitual vomiting. The medical care team, the patients, and their families together decided to try HPN as a last resort. Informed consent for HPN was obtained from the patient and the family. All patients were hospitalized and catheters were inserted by surgeons or anesthesiologists at Tokyo Women's Medical University. During hospitalization, for approximately 1 week, nurses in the Department of InHome Medical Care instructed patients and their family in how to perform HPN until they could do it independently. A series of FULCALIQ ${ }^{\circledR}$ solutions (Tanabe Seiyaku Co., Ltd. \& Terumo Corporation, Tokyo, Japan) were used. FULCALIQ $^{\circledR}$ does not require the separate addition of vitamins because it contains multivitamins, dextrose, amino acids, zinc, and electrolytes supplied in a triple-chamber bag. The total energy of FULCALIQ ${ }^{\circledR} 1$, FULCALIQ ${ }^{\circledR} 2$, and FULCALIQ $^{\circledR} 3$ are $560 \mathrm{kcal}, 860 \mathrm{kcal}$, and 1,160 kcal, respectively. We discussed the daily content of intravenous feedings with the patients, and they decided which bag they could accept. Although most patients with AN hate ingesting fat, they were taught the importance of essential fatty acids. An infusion of a $250 \mathrm{~mL}$ intravenous fat emulsion was used once or twice a week except for Case 3, whose allergy to dairy and soy products prohibited ingestion; instead, Case 3 took grape seed oil and sesame oil orally, which contain high levels of omega- 6 fatty acids. Case 7 took $1,000 \mathrm{~mL}$ physiological saline, $200 \mathrm{~mL}$ of $50 \%$ glucose, Hicaliq ${ }^{\circledR} 3$ (Terumo Corporation), which is a TPN solution containing dextrose, zinc, and electrolytes, and $400 \mathrm{~mL}$ of $\mathrm{Kidmin}^{\circledR}$ injection (Otsuka Pharmaceutical Co., Ltd., Tokyo, Japan), which is an amino acid solution for renal failure.

Visiting nurses helped five patients once a week and checked to see whether infusions were being done correctly. Five patients had cooperation from neighborhood hospitals when they needed urgent medical assistance. Although the home central venous feeding method instruction management charge and the expense of infusions were 62,500 yen and approximately 40,000 yen, respectively, the total monthly cost was estimated to be one third the cost of hospitalization. Moreover, only $30 \%$ of those costs were out-of- pocket expenses for patients; their taxes were subtracted according to the "large amount of medical expenses" tax reduction.

The HPN observation period of the seven cases ranged from 14 to 104 months. Case 1 continued HPN, Case 5 stopped HPN, and Cases 2, 3, 4, 6, and 7 ended HPN. Case 1 suffered from exit-site infection but was successfully treated with antibiotics. She also experienced catheter rupture and had the catheter removed. However, she subsequently lost weight and had a new catheter reinserted. During HPN treatment, her cognition improved and she was able to gain body weight. She gained $9 \mathrm{~kg}$ due to HPN and a reduced caloric intake of infusion by switching from FULCALIQ $^{\circledR} 3$ to FULCALIQ ${ }^{\circledR} 2$ but could not eat enough to maintain her body weight. She showed liver dysfunction and biliary sludge. However, her liver dysfunction improved after the reduction of total caloric intake of infusion and her liver echogram did not indicate fibrosis. Case 2 gained $9 \mathrm{~kg}$ and ended HPN following a catheter-related bloodstream infection (CRBSI). However, she subsequently lost weight and was hospitalized twice. Case 3 could work part-time due to an improvement of her nutritional state by HPN, but experienced a CRBSI and had the catheter removed. Because she could not keep her body weight up, she had to resume HPN and subsequently gained $6 \mathrm{~kg}$. However, she got another CRBSI and then ended HPN. She learned the high risk of CRBSI of HPN and enthusiastically increased her body weight by more than $8 \mathrm{~kg}$ to a BMI of $18.8 \mathrm{~kg} / \mathrm{m}^{2}$, thus resulting in the resumption of menstruation. Although Case 4 showed hyponatremia and hypokalemia due to large amounts of vomiting, she regained an understanding of her illness, successfully increased her body weight to a BMI of $18.4 \mathrm{~kg} / \mathrm{m}^{2}$ and then ended HPN. She resumed menstruation and has worked full-time. Case 5 gained $5 \mathrm{~kg}$ of body weight and controlled her hypokalemia. However, she asked that HPN be withdrawn due to fear of further weight gain. We did not force her to continue HPN and she stopped HPN after 17 months. However, she was hospitalized in a neighborhood hospital twice due to dehydration and administered glucose and electrolyte infusion via an HPN catheter. Case 6 was able to control her hypokalemia and work part-time while receiving HPN. However, she sometimes threw away the contents of the infusion because of a fear of weight gain. Therefore, HPN was ended when she developed a CRBSI. However, she learned that body weight gain allowed her to work and make money. She became open to medication for obsessive-compulsive disorder and increased her body weight to a BMI of $13.1 \mathrm{~kg} / \mathrm{m}^{2}$ by herself. Although Case 7 complained of an increase in water volume or energy of infusion, the content of infusion was decided based on her serum BUN/creatinine levels. She suffered from hypercalcemia due to dehydration and relative excess of vitamin D. She increased her body weight to a BMI of $14.4 \mathrm{~kg} / \mathrm{m}^{2}$ and became less negative to treatment. Her current serum BUN and creatinine levels were $18.3 \mathrm{mg} / \mathrm{dL}$ and $2.67 \mathrm{mg} /$ $\mathrm{dL}$, respectively. Unfortunately, she got a CRBSI, ended 
HPN, and currently receives peripheral infusions three times a week at a hospital near her house.

All seven patients were able to avoid re-hospitalization for life-threatening emaciation, renal failure, or electrolyte imbalances during HPN therapy. Case 1 was able to undergo minor surgery that had been postponed due to her malnutrition. Cases 2 and 7 enjoyed trips with their families, which were previously not possible. Cases 3 and 6 were able to work while receiving HPN therapy. Case 3 and 4 completely recovered from $\mathrm{AN}$.

\section{Discussion}

Several problems were experienced with HPN that were specific to the presented cases. These problems were associated with the application criteria of HPN, special considerations for using HPN, the endpoints of HPN, and medical economics.

The decision to use the TPN method for very limited and strictly chosen patients with AN has more advantages than disadvantages compared with oral feeding (9) or enteral nutrition. Because most patients with AN have strong phobias of weight gain, the treatment of these patients using TPN may be dangerous, even if performed in a hospital (4). The risk would be greater in a home where constant medical supervision is absent (7). Therefore, the use of HPN for patients with AN should be strictly controlled based on specific criteria. Our institution has the following seven criteria for the use of HPN in patients with $\mathrm{AN}$ : 1) the patient shows severe emaciation of around $<55 \%$ of the ideal body weight; such patients are recommended for urgent admission according to the 2007 guidelines for AN by the Survey Committee for Eating Disorders in Japan; 2) the patient has life-threatening complications that cannot be addressed without TPN at the hospital when other nutritional supports fail (including oral feeding or enteral nutrition); 3) the patient has a history of repeated hospitalizations and aggravation of disease after discharge, and the family thus suspects that the next hospitalization will result in the same outcome as before; 4) the patient is unwilling to enter a hospital; 5) the patient (as well as the family) can learn how to perform HPN, perform it, and provide informed consent for HPN; 6) the patient lives with his/her family or loved ones; and 7) the patient can obtain assistance from home nursing care, a pharmacy, or a regional hospital.

The most frequent HPN complications are infections $(10,11)$. The infection rate is highly variable and depends on the patient's clinical conditions and the antiseptic techniques used by the administrators. The CRBSI rate has been reported to be $0.38-4.58 / 1,000$ days (12-14). Four of the present seven cases experienced CRBSI. The infection rate was $0.93 / 1,000$ days. Although liver failure is uncommon in adults receiving long-term parenteral nutrition (15), Case 1 showed mild liver dysfunction and biliary sludge (16) under supplementation with necessary fatty acids. In this circumstance, reducing the number of calories in the infusion may improve liver dysfunction; namely a change from $1,160 \mathrm{kcal}$ to $860 \mathrm{kcal}$ a day normalized the liver dysfunction in Case 1. It has been previously reported that patients with HPN suffer from fatigue and depression and experience limits in social activities (17). AN patients and their families must carry out HPN with proper antiseptic techniques. Therefore, the difficulties and complaints concerning HPN need to be acknowledged, and the patient's efforts need to be praised.

It is possible that patients receiving HPN may use their central venous catheters in various ways to engage in selfharm (18). However, no such incidents were seen in the present cases. Of particular note, patients with AN persistently worry about weight gain. Therefore, sudden increases in the energy content of HPN need to be avoided. Prolonging the patient's life via HPN may be enough. Patients with AN need to be reassured that HPN can be stopped at any point.

It is well known that chronic starvation changes physical, psychological, and social functioning even in healthy subjects. In the Minnesota experiment, healthy subjects who took part in 3 months of semi-starvation showed an increase in depression, hysteria, neurosis, apathy, compulsion, changes in personality, and impaired cognition (19). Psychotherapy is not effective in malnourished patients. TPN has been used to restore the psychological stability of patients with AN (20). Although Cases 3, 4, 6, and 7 were chronically treatment-resistant patients with AN, Cases 3 and 4 were able to recover and Cases 6 and 7 did not need hospitalization after ending HPN. Re-feeding by HPN may improve these starvation-induced emotional and cognitive symptoms in enduring patients with AN.

The end-point of HPN in a severe AN patient is ideally achievement of a desired weight (not the ideal body weight), control of medical complications without HPN, and sufficient oral intake including enteral nutrition therapy. It is clear that HPN should be temporary and only a life-saving measure for patients with AN (21). However, HPN was not ended in Case 1 who was unable to maintain her minimum body weight due to persistent digestive symptoms without HPN. In the future, determining how to end HPN in such a patient is a serious concern that needs to be addressed.

AN is an expensive illness to treat and it is also associated with a high mortality rate. A study in Germany found that the cost of hospitalization of patients with AN was markedly higher than the average hospitalization cost (22). Furthermore, some insurance companies refuse payment for such care in the United States. In Japan, the medical cost for one month of HPN is estimated to be one third the cost of hospitalization. Therefore, HPN may make sense from an economic standpoint for suitable patients.

In conclusion, HPN may be a useful treatment option for patients with enduring AN to avoid multiple hospitalizations, despite possible HPN-related complications. However, the occurrence of CRBSI and the termination of HPN in patients with severe AN who cannot control their physical 
morbidities remain as major problems which must be carefully taken into consideration when determining the optimal treatment regimens for such cases.

The authors state that they have no Conflict of Interest (COI).

\section{Acknowledgement}

We would like to thank the staff members of the Department of the 2nd Medicine, Surgery, Anesthesiology and the Department of In-Home Medical Care in Tokyo Women's Medical University for their technical assistance.

This study was supported by funding from the Ministry of Health, Labour and Welfare of Japan.

\section{References}

1. Arcelus J, Mitchell AJ, Wales J, Nielson S. Mortality rates in patients with anorexia nervosa and other eating disorders. A metaanalysis of 36 studies. Arch Gen Psychiatry 68: 724-731, 2011.

2. Maloney MJ, Farrell MK. Treatment of severe weight loss in anorexia nervosa with hyperalimentation and psychotherapy. Am J Psychiatry 137: 310-314, 1980.

3. Meguid MM, Muscaritoli M. Current uses of total parenteral nutrition. Am Fam Physician 47: 383-394, 1993.

4. Diamanti A, Basso MS, Castro M, et al. Clinical efficacy and safety of parenteral nutrition in adolescent girls with anorexia nervosa. J Adolesc Health 42: 111-118, 2008.

5. Dudrick SJ, O'Donnell JJ, Englert DM, et al. 100 patient-years of ambulatory home total parenteral nutrition. Ann Surg 199: 770$781,1984$.

6. Gouttebel MC, Saint-Aubert B, Jonquet O, Astre C, Joyeux H. Ambulatory home total parenteral nutrition. JPEN J Parenter Enteral Nutr 11: 475-479, 1987.

7. Latzer Y, Eysen-Eylat D, Tabenkin H. A case report: treatment of severe anorexia nervosa with home total parenteral hyperalimentation. Int J Eat Disord 27: 115-118, 2000.

8. Hotta M, Fukuda I, Sato K, Hizuka N, Shibasaki T, Takano K. The relationship between bone turnover and body weight, serum insulin-like growth factor (IGF) I, and serum IGF-binding protein levels in patients with anorexia nervosa. J Clin Endocrinol Metab 85: 200-206, 2000.

9. Mehler PS, Weiner KL. Use of total parenteral nutrition in the re- feeding of selected patients with severe anorexia nervosa. Int J Eat Disord 40: 285-287, 2007.

10. Bozzetti F, Mariani L, Bertinet DB, et al. Central venous catheter complications in 447 patients on home parenteral nutrition: an analysis of over 100.000 catheter days. Clin Nutr 21: 475-485, 2002.

11. Shirotani N, Iino T, Numata $K$, Kameoka S. Complications of central venous catheters in patients on home parenteral nutrition: an analysis of 68 patients over 16 years. Surg Today 36: 420-424, 2006.

12. Cuerda CC, Breton LI, Bonada Sanjaume A, et al. [Catheterrelated infection in home-based parenteral nutrition: outcomes from the NADYA group and presentation of a new protocol]. Nutr Hosp 21: 132-138, 2006 (in Spanish, Abstract in English).

13. Dreesen M, Foulon V, Spriet I, et al. Epidemiology of catheterrelated infections in adult patients receiving home parenteral nutrition: a systematic review. Clin Nutr 32: 16-26, 2013.

14. Gillanders L, Angstmann K, Ball P, et al. A prospective study of catheter-related complications in HPN patients. Clin Nutr 31: 3034, 2012.

15. Salvino R, Ghanta R, Seidner DL, Mascha E, Xu Y, Steiger E. Liver failure is uncommon in adults receiving long-term parenteral nutrition. JPEN J Parenter Enteral Nutr 30: 202-208, 2006.

16. Dray X, Joly F, Reijasse D, et al. Incidence, risk factors, and complications of cholelithiasis in patients with home parenteral nutrition. J Am Coll Surg 204: 13-21, 2007.

17. Huisman-de Waal G, Bazelmans E, van Achterberg T, et al. Predicting fatigue in patients using home parenteral nutrition: a longitudinal study. Int J Behav Med 18: 268-276, 2011.

18. Stern JM, Jacyna N, Lloyd DA. Review article: psychological aspects of home parenteral nutrition, abnormal illness behaviour and risk of self-harm in patients with central venous catheters. Aliment Pharmacol Ther 27: 910-918, 2008.

19. Keys A. The residues of malnutrition and starvation. Science 112: 371-373, 1950.

20. Price BS, Levine EL. Permanent total parenteral nutrition: psychological and social responses of the early stages. JPEN J Parenter Enteral Nutr 3: 48-52, 1979.

21. Shils ME. The advent of home parenteral nutrition support. Annu Rev Nutr 30: 1-12, 2010.

22. Krauth C, Buser K, Vogel H. How high are the costs of eating disorders - anorexia nervosa and bulimia nervosa - for German society? Eur J Health Econ 3: 244-250, 2002.

(C) 2014 The Japanese Society of Internal Medicine http://www.naika.or.jp/imonline/index.html 